\title{
PENDIDIKAN SEJARAH DALAM PERSPEKTIF PEMIKIRAN IBNU KHALDŪN
}

\author{
Abdurrahman Kasdi \\ STAIN Kudus, Jawa Tengah, Indonesia. \\ abdurrahmankasdi@gmail.com
}

\begin{abstract}
Kajian dalam artikel ini bertujuan untuk mengeksplorasi konsep dan teori pendidikan sejarah Ibnu Khaldūn dalam kitab Muqaddimah. Pemikiran Ibnu Khaldūn yang telah mengkristal dalam Muqaddimah, banyak mempengaruhi format peradaban masyarakat. Kebesarannya selama berabad-abad ternyata banyak mengundang komentar dari berbagai kalangan. Tidak sedikit yang memuji dan mengagumi karyanya, baik dari orientalis maupun pemikir Islam sendiri. Pendekatan dalam kajian ini adalah kajian kepustakaan. Hasil penelitian menunjukkan ini adalah bahwa ibnu kholdūn piawai dalam menggulirkan ide-ide barunya berupa teori sejarah dan peradaban umat Islam, ia juga termasuk orang yang memberikan kontribusi dalam mempropagandakan teori ini di dunia Arab kontemporer. Bahkan ia pernah mengatakan bahwasanya Ibnu Khaldūn telah mendahului Montesque dalam teorinya tentang pengaruh miliu terhadap moral; Hegel dalam teori dialektikanya; Karl Marx dalam teorinya tentang urgenitas, social clash dan surplus nilai. Konsep dan teori yang tertuang dalam magnum opusnya, Muqaddimah, telah memberikan inspirasi para intelektual Barat maupun Islam dalam membangun peradaban. Misbāh al-Āmily menjadikan pemikiran Ibnu Khaldūn sebagai variabel dalam melakukan studi komparatif antara pemikiran Arab dengan pemikiran Yunani.
\end{abstract}

Kata kunci: pendidikan, sejarah, Ibnu Khaldūn 


\begin{abstract}
EDUCATION HISTORY IN IBN KHALDŪN THOUGHT'S PERSPECTIVE. This study aims to explore the concept of educational theory and the history of Ibn Khaldun in the Muqaddimmah book. Ibn Khaldun thought which has crystallized in the Muqaddimmah, gives many affect on the format of the civilization community. Its greatness for centuries invited many comments from various circles. Not a few who praised and admired his work, both from the orientalist as well as the Islamic thinkers. This study uses library research. The result of this study is that Ibn Khaldūn is clever in delivering his new ideas either a theory of history and civilization of the Muslims, he is also included the people who contributed to propagating this theory in the contemporary Arab world. Even, he ever said that Ibn Khaldun had got the start of Montesque in his theory of the influence of miliu against moral; Hegel in his dialectical theory; Karl Marx in his theory of urgency, social clash and surplus value. The concepts and theories contained in his magnum opus, Muqaddimmah, has inspired both the Western and the Moslems intellectuals in building the civilization. Misbâh al-Āmily make the Ibn Khaldun's thought as a variable in conducting the comparative studies between Arab thought with the thought of Greece.
\end{abstract}

Keywords: educational, history, Ibn Khaldūn

\title{
A. Pendahuluan
}

Peradaban manusia mengalami jatuh bangun. Ketika Islam jaya, Barat belum mengenal peradaban sehingga ilmu pengetahuan banyak dihasilkan oleh kekhalifahan Islam (Bani Umayyah dan Abbasiyah). Hal ini berlangsung cukup lama sampai akhirnya terjadi perang Salib, di mana tentara Salib (Barat) mempelajari dan tidak sedikit yang mengadopsi produk ilmu pengetahuan yang dihasilkan Islam. Di saat Barat mengalami kemajuan yang pesat dalam ilmu pengetahuan dan teknologi, Islam mengalami kemunduran. Bahkan ketika terjadi penyerangan tentara Mongol, semua produk peradaban dihancurkan. Bangunan diratakan dengan tanah, umat Islam dibunuh dan buku-buku dibakar.

Kembalinya umat Islam untuk membangun peradabannya merupakan keharusan dan ini tidak bisa diklaim dengan tuduhan menghalangi Barat. Ketika Barat maju, banyak terjadi penjajahan dimuka bumi. Namun ketika Islam yang maju, tidak ada satu pun 
bentuk penjajahan yang dilakukan oleh umat Islam. Kerena Islam sendiri merupakan agama yang "Rahmatan lil 'Alamin".

Salah satu tokoh yang banyak memberikan kontribusi dalam wacana pengembangan peradaban dunia, khususnya umat Islam adalah IbnuKhaldūn. Pemikiran Ibnu Khaldūn, khususnya teori sejarahnya telah merambah keseluruh struktur masyarakat. Semua kalangan; baikrakyat, pemerintah maupun kaum terpelajar mempunyai semangat yang tinggi untuk mempelajari pemikiran sejarahnya. Hal ini karena sejarah merupakan disiplin ilmu yang dipelajari secara luas oleh bangsa-bangsa dari berbagai generasi. Sejarah mengeksplorasi keterangan tentang peristiwa-peristiwa politik, negara dan peristiwaperistiwa masa lampau.

\section{B. Pembahasan}

\section{Biografi Ibnu Khaldūn}

Ibnu Khaldūn mempunyai nama lengkap Waliyuddin Abu Zaid Abdurrahmān bin Muhammad Ibnu Khaldūn al-Hadrami alIshbili. Beliau dilahirkan di Tunisia pada awal Ramadlan $732 \mathrm{H}$ atau tanggal 27 Mei 1332 (Khaldūn, 1951: 1). dan wafat di Kairo pada tanggal 17 Maret 1406. Keluarganya berasal dari Hadramaut yang kemudian berimigrasi ke Sevilla (Spanyol) pada abad ke-8 setelah semenanjung itu dikuasai Arab Muslim. Keluarga ini pro Umayyah dan selama bertahun-tahun menduduki posisi tinggi dalam politik di Spanyol sampai akhirnya hijrah ke Maroko. Setelah dari Maroko, mereka menetap di Tunisia.

Ia sering berinteraksi dan terlibat dalam kegiatan intelektual dikota kelahirannya, disamping mengamati dari dekat kehidupan politik. Kakeknya pernah menjabat menteri keuangan di Tunis, sementara ayahnya sendiri adalah seorang administrator dan perwira militer. Ibnu Khaldūn di masa kecilnya ternyata lebih tertarik pada dunia ilmu pengetahuan. Di usianya yang relatif muda, ia telah menguasai ilmu sejarah, sosiologi dan beberapa ilmu klasik, termasuk ulum aqliyah (ilmu filsafat, tasawuf dan metafisika). Kecintaannya pada ilmu membuatnya mempelajari ilmu pada sejumlah guru, yang terpenting adalah: Abu Abdillah Muhammad bin al-ArabialHashasyiri, Abu al-Abbas Ahmad bin al-Qushshar, dan guru lainnya. 
Ibnu Khaldūn banyak terlibat dalam kegiatan politik yang mengantarkannya menduduki posisi strategis. Khaldūn muda oleh Sultan Abu Inan dari Fez, Maroko mendapatkan kepercayaan untuk menjadi sekretarisnya, padahal waktu itu usianya masih 20 tahun. Dia menetap di Maroko antara tahun 1354 sampai 1362 dan akhirnya meninggalkan Afrika utara menuju Granada, Spanyol pada tanggal 26 Desember 1362. Keputusan ini diambil karena situasi politik Maroko menghangat dan sebelumnya dia sempat dipenjara selama 21 bulan karena dituduh berkomplot dengan Pangeran Muhammad, menggulingkan Abu Inan dari kursi kesultanan.

Pada saat di Granada Spanyol, Khaldūn disambuthangat oleh penguasa di sana. Bahkan di tahun berikutnya, Sultan menunjuknya sebagai duta Raja Castilla, Pedro, untuk mengadakan perdamaian antara keduanya.Tugas ini diselesaikan dengan baik dan ia menjadi seorang tokoh politik peringkat pertama. Keberhasilannya ini ternyata membuat iri Ibnu Khatib yang merusak hubungannya dengan Sultan. Sehingga, sebagaimana diuraikan dalam at-Ta'rif, Ibnu Khaldūn pergi ke Bijayah. Kedatangannya di sana mendapatkan sambutan baik dari sang Sultan dan ia diberi jabatan" $H$ ijäbah",setingkat Perdana Menteri. Kemudian ia pindah lagi menuju ke Biskarah, karena kedekatannya dengan Ahmad Ibnu Yusuf Ibnu Mazni, penguasa di sana.

Pengalamannya yang begitu banyak menjadi bahan penting baginya untuk menyusun teori dan pokok pikirannya dalam Muqaddimah dan beberapa buku lainnya yang menjadi referensi sejarah peradaban umat manusia. Diakhir kehidupannya, ia tidak lagi tertarik dengan glamour kehidupan dunia. Bahkan banyak sekali jabatan politik yang ia tolak, karena ia ingin konsentrasi dalam kontribusi intelektual.

\section{Beberapa Pemikiran Ibnu Khaldūn}

Menurut Ibnu Khaldūn, al-Umrān merupakan kumpulan dari segala ilmu pengetahuan, termasuk di antaranya ilmu sosiologi (Al-Âmily, 1988: 318). Al-Umrān mempunyai makna luas, meliputi seluruh aspek aktifitas kemanusiaan, diantaranya frame geografi peradaban, pereko-nomian, sosial, politik, dan ilmu pengetahuan. Maksud dari al-umrân dalam kerangka pemikiran Ibnu Khaldūn sebagaimana ditegaskan al-Āmily adalah ilmu metodologi umum yang 
khusus membahas tentang dasar-dasar peradaban, dan dengannya tercapai puncak peradaban dunia (al-Āmily, 1988: 311-317).

Manusia menurut Ibn Khaldūn membutuhkan interaksi dalam menumbuhkan peradaban, karena menurutnya manusia secara tabiat adalah makhluk sosial. Oleh karena itu, manusia harus berkumpul, karena hal ini merupakan karakteristik kesosialannya. Hal seperti ini mengandung makna esensial dari sebuah peradaban. Pertemuan sangat urgen bagi kehidupan manusia. Tanpa pertemuan, keberadaannya tidak sempurna. Tuhan berkeinginan memakmurkan bumi ini oleh mereka semua dan memberikan khilafahnya hanyalah kepada manusia (Al-Maghriby, 1983: 41-43). Ibnu Khaldūn mempunyai teori yang terkenal, "tingkat keberadaan kekayaan" bisa menentukan kelas sosial. Dalam hal ini, ia berkata; ... kemudian kekayaan itu terbagi-bagi di masyarakat, dan membentuk tingkat kedudukan sosialnya. Kelas paling tinggi adalah kedudukan raja, tidak ada yang tinggi lagi yang bisa memberikan sesuatukepada manusialainnya. Sedangkan kelas bawahan adalah dari orang yang tidak mempunyai apa-apa di kalangan yang sejenisnya, serta di antara kalangan yang berbeda-beda kelasnya. Kemudian ia menghubungkan sifat kebaikan dengan kefakiran. Menurutnya bahwa kita banyak menemukan dari orang-orang yang selalu bersenang-senang dengan kemewahan dan kemuliaan, tetapi tidak mencapai pada tingkat kebahagiaan (Al-Maghriby, 1983: 390-391).

Banyak ilmu pengetahuan yang dikuasai oleh Ibnu Khaldu $>n$. Ia bukan hanya seorang filosuf, melainkan juga sosiolog, politikus dan ahli sejarah. Sosiologi menurutnya merupakan sarana untuk memahami sejarah dan kondisi sosial masyarakat pada suatu generasi, proses perubahan dalam suatu masyarakat, faktor dan pengaruhnya dalam peta peradaban suatu bangsa. Dalam konteks sosiologi, Ibnu Khaldūn membagi masyarakat menjadi tiga tingkatan: pertama, masyarakat primitif (wahsy), dimana mereka belum mengenal peradaban, hidup berpindah-pindah dan hidup secara liar. Kedua, masyarakat pedesaan, hidup menetap walaupun masih sederhana. Mata pencaharian mereka lebih didominasi dari pertanian dan peternakan. Dalam kelas ekonomi mereka dibagi menjadi tiga, yaitu: petani, penggembala sapi dan kambing serta penggembala unta. Sedangkan yang ketiga, masyarakat kota. Masyarakat ini menurutnya 
sebagai masyarakat berperadaban, di mana mata pencahariannya dari perdagangan dan perindustrian.Tingkat ekonomi dan kebudayaan cukup tinggi, mampu mencukupi kebutuhannya bukan hanya kebutuhan pokok, melainkan juga kebutuhan sekunder (Al-Maghriby, 1983: 120).

Ia menyebutkan moral badui dan berperadaban terbagi ke dalam dua macam; datang secara alami dan muncul dengan direkayasa. Menurutnya, masyarakat badui lebih memiliki sifat pemberani ketimbang kalangan masyarakat kota. Sebab utamanya, masyarakat kota banyak menikmati ketenangan, beristirahat, tenggelam dalam kenikmatan dan bermewah-mewahan. Generasi demi generasi telah lahir dari kedua orangtuanya, baik lelaki atau wanita. Anak lelaki mengikuti kebiasaan bapaknya, sedangkan yang wanita mengikuti ibunya. Sementara masyarakat badui kurang mengadakan perkumpulan dalam sebuah komunitas, mereka melakukan pertahanan terhadap diri mereka sendiri, condong menggunakan senjata dan tidak mengandalkan orang lain. Dalam konteks iklim dan moral, Ibn Khaldūn menganalisis juga tentang "pengaruh iklim terhadap moral manusia." Wilayah yang diduduki oleh orang-orang dengan udara panas seperti Sudan dan negara Arab, biasanya mereka kurang berhati-hati dan banyak bergembira. Begitu juga dengan masyarakat yang berasal dari teluk. Sedangkan penduduk yang wilayahnya kering biasanya mereka mempunyai tabiat selalu merasakan kesedihan. Sebab utamanya, karena mereka tinggal di wilayah dan daerah yang iklimnya bisa mempengaruhi moral kehidupan.

Terkait dengan struktur masyarakat, ia membaginya dalam tiga format, yaitu: bangsa Arab, Barbar dan 'Ajam. Dari tiga struktur tersebut, ia menempatkan bangsa Arab pada masyarakat pedesaan yang primitif, karena mereka hidup sebagai penggembala unta yang harus berpindah-pindah (Al-Maghriby, 1983: 121). Maksud Arab ini konotasinya lebih dekat kepemaknaan badui. Mereka terbiasa mempertahankan diri dari musuh dan tantangan yang setiap saat menghantui. Begitu juga dengan alam yang tidak bersahabat. Mereka tidak pernah melepaskan senjatanya, karena setiap saat bahaya akan mengancam. Dengan pengalaman ini, bangsa Arab menurut Ibnu Khaldūn mampu merebut kekuasaan dari pihak lain 
dengan 'așhabiyah-nya. Namun, kekuasaan ini cepat lepas karena kondisi mereka yang berpindah-pindah. Padahal, kekuasaan itu bisa dipertahankan melalui dukungan solidaritas dari golongannya yang terus membantu dan membelanya dalam setiap waktu. Hal ini sulit diperoleh karena setiap waktu, mereka dituntut untuk berkelana, sebagai penggembala.

Menurut Ibnu Khaldūn kondisi diatas semakin lama mengalami pergeseran, dengan bergantinya waktu. Struktur masyarakat Arab juga mengalami perubahan berdasarkan perubahan orientasi dan sosiologi, sebagaimana yang dianalisis oleh Mahmūd Isma'il, dalam bukunya Sosiologiy al-Fikral-Istamy. Perubahan yang terjadi dalam masyarakat, bukanlah merupakan pengaruh dari luar, melainkan merupakan reaksi yang timbul dalam intern masyarakat yang menjadi tabiatnya. Menurutnya, akar sosiologi Arab dapat ditelusuri dari tiga fase dan struktur sosial yang merupakan bentangan sejarah Arab klasik sebelum masa kenabian. Ketiga struktur tersebut nantinya akan memberikan pengaruh yang besar terhadap wacana pemikiran sesudahnya (Isma’il, 1988: 46-77).

Pertama, struktur rohaniawan. Kelompok ini hidup dan berkembang di daerah gurun. Mereka sangat fasih melantunkan syairsyairArab. Kedua, struktur feodalisme yang dimulai sejak 1300-527 SM. Dari tinjauan sejarah, struktur ini merupakan generasi pertama yang telah mengalami perubahan. Perubahan dari rohaniawan ke feodalisme ditandai dengan tumbuhnya solidaritas Arab, seperti negeri Qitban, Muayan, Saba' dan negeri Hamir. Namun pengaruh dari perubahan ini menjadikannegeri- negeri yang pada mulanya bekerja sama dalam hal pengairan, selanjutnya berangsur menjadi kekerasan. Kelompok yang kuat menindas yang lemah, yang kaya memeras yang miskin dan sejak saat itulah mereka terbagi dalam kasta. Tanah-tanah pertanian dibagikan kepada para pemimpin sektor/wilayah.

Ketiga, struktur borjuisme. Di antara indikasi yang dipandang representatif untuk menggambarkan kehidupan kaum borjuis Arab saat itu, antara lain, lukisan yang tertera pada mata uang. Lukisan tersebut meliputi nama-nama raja, kota dan lambang kebesaran. Menurut para sosiolog, lukisan nama-nama raja menunjukkan bahwa masyarakat Arab pra-kenabian dikelompokkan dalam dua kategori 
besar, yaitu: kelompok yang berpegang pada agama, tetapi cenderung berperilaku sekuler dan kelompok yang cenderung sekuler.

Arab sebelum kedatangan Islam merupakan komunitas badui yang terbelakang dan tidak diperhitungkan dalam peradaban dunia. Sikap kebinatangan mengalahkan prinsip humanisme, yang kuat menindas yang lemah, yang kaya menindas yang miskin. Sehingga persaudaraan berubah menjadi permusuhan. Tamaddun dalam kontek dunia Arab, jelas mempunyai korelasi yang erat dengan datangnya Islam yang memberikan jiwa bagi lahirnya peradaban. Pasca kenabian, ideologi menjadi mainstream dan tatanan baru yang menyikapi seluruh aspek duniawi. Pada saat itu, secara sosio-historis Nabi Muhammad merupakan pemegang risalah sekaligus penggerak peradaban umat Islam.

Ibnu Khaldūn juga mengembangkan tradisi hermeneutik, yang kemudian dikembangkan oleh generasi sesudahnya, termasuk di antaranya Arkaun dan Naṣhr Hamid Abụ Zaid (Hidayat, 1996: 25). Dalam wacana hermeneutika, sebuah tradisi akan mati, kering dan mandeg jika tidak dihidupkan secara terus-menerus melalui penafsiran ulang sejalan dengan dinamika sosial. Sebagai seorang sosiolog yang juga pemerhati sejarah, Ibnu Khaldūn menganjurkan untuk memahami sejarah, sebagai kondisi pelaku sejarah.

Tradisi hermeneutika ini terdiri dari tiga elemen pokok, yaitu: pengarang, teks dan pembaca. Ketiganya mempunyai dunia tersendiri, sehingga harus terjalin hubungan yang dinamis, dialogis dan terbuka. Ada interaksi yang saling terkait antara ketiganya. Di satu sisi seorang pembaca ketika berhadapan dengan teks,hasil yang ia peroleh tergantung pada keberaniannya mengenali arti dan muatan teks. Sedangkan disisi lain, pembaca dituntut untuk mengenali lebih jauh terhadap pribadi pengarang sehingga mampu menangkap aspirasi yang ada dalam nurani pengarang secara keseluruhan. Sering pembaca menarik benang merah yang tidak sesuai dengan pesan pengarang, karena kurang memahami maksud pengarang tersebut.

\section{Pendidikan Sejarah Ibnu Khaldūn}

Menurut Ibnu Khaldūn, struktur filsafat sejarah terdiri dari: pelaku sejarah, substansi sejarah dan pembaca sejarah. Seorang pembaca sejarah harus menguasai kaidah dalam periwayatan sejarah, 
karakteristik pelaku sejarah, tabiat yang ada, problematika perpecahan umat dan sebagainya (Khaldūn,1983: 28). Hal ini agar sejarah yang dibacanya dapat dipahami secara utuh dan terhindar dari keterputusan mata rantai generasi (Al-Āmily, 1988:315). Seorang ahli sejarah ketika menerima riwayat atau memaparkan suatu peristiwa harus memahami fenomena dan kondisi sosial masyarakat pada waktu itu. Sebab, sejarah pada masa lalu tidak mungkin terulang, demikian halnya dengan prestasi-prestasi sejarah yang terjadi. Kalaupun seseorang ingin memahami substansi sejarah, berarti harus menafsirkan sejarah berikut kondisi sosial yang ada. Sejarah menurutnya terdiri dari dua unsur, yaitu: pertama, unsur sosiologis (tarikh batin) dan kedua, unsur keabsahan riwayat (tarikh dzahir).

Dalam pengertian yang paling sederhana filsafat sejarah adalah tinjauan terhadap peristiwa-peristiwa historis secara filosofis untuk mengetahui faktor-faktor esensial yang mengendalikan perjalanan peristiwa-peristiwa historis itu, untuk kemudian mengiktisarkan hukum-hukum yang tetap, yang mengarahkan perkembangan berbagai bangsa dan negara dalam berbagai masa dan generasi. Dalam hakikat sejarah, terkandung pengertian observasi dan usaha mencari kebenaran (tahqiq), keterangan yang mendalam tentang sebab dan asal sesuatu. Pengetahuan tentang substansi, esensi dan sebab-sebab terjadinya suatu peristiwa. Para sejarawan muslim terkemuka telah membicarakan teori dan peristiwa sejarah secara luas dan mendalam. Selain Ibnu Khaldūn yang mengarang kitab Muqaddimah, ada juga Ibnu Ishaq, yang mengarang kitab Sirah Muhammad dan At-Thabari yang mengarang kitab Tarikh Al-Umam Wa Al-Mulūk.

Kharakteristik Ibnu Khaldūn sebagai seorang sejarawan mempunyai keistimewaan yang berbeda dibandingkan dengan ahli sejarah lainnya khususnya dalam mengeksplorasi sejarah. Dia mampu menegakkan kembali otoritas kebenaran sejarah melalui pembacaan yang kritis terhadap peristiwa masa lalu. Dalam Muqaddimahnya, ia membagi pembahasan tentang sejarah dan peradaban umat manusia ke dalam empat bagian yang terdiri dari: satu pengantar dan tiga pokok bahasan (Al-Āmily, 1988:8).

Pertama, pengantar yang menguraikan tentang manfaat 
besar historiografi (ilmu sejarah), pengertian tentang segala metode historiografi dan secara sepintas menyebutkan kesalahan para sejarawan. Kedua, pembahasan pertama yang menguraikan tentang peradaban('umran) dan ciri-cirinya yang hakiki. Ciri tersebut mencakup kekuasaan, pemerintahan, mata pencaharian, penghidupan, keahlian-keahlian dan ilmu pengetahuan dengan segala bentuknya. Ketiga, pembahasan kedua yang menguraikan sejarah, generasi, dan negara sejak terciptanya alam hingga kini. Dalam pokok bahasan ini juga mengandung ulasan sekilas tentang bangsa-bangsa terkenal dan negara-negara yang sezaman dengan mereka. Seperti: bangsa Nabti, Siryani, Persia, Israel, Qibti, Yunani, Rumawi, Turki dan Eropa Keempat, pembahasan ketiga menguraikan sejarah bangsa Barbar dan Zanathah, yang merupakan bagian dari mereka, khususnya kerajaan dan negara-negara Maroko.

Para pemikir sejarah mengatakan bahwa Ibnu Khaldūn merupakan penggagas filsafat sejarah. Hal ini bisa dibuktikan dari berbagai karya Ibnu Khaldūn yang tersebar dibelahan dunia dan gagasannya yang cemerlang mengenai sejarah. Menurutnya, masyarakat adalah makhluk historis yang hidup dan berkembang sesuai dengan hukum-hukum khusus yang berkenaan dengannya. Hukum-hukum tersebut dapat diamati dan dibatasi lewat pengkajian terhadap sejumlah fenomena sosial. Ibnu Khaldu $>$ n berpendapat bahwa 'ashabiah merupakan asas berdirinya suatu negara, dan faktor ekonomis adalah salah satu faktor terpenting yang menyebabkan terjadinya perkembangan negara.

\section{Sejarah Perkembangan Negara}

Menurut Ibnu Khaldūn negara adalah suatu komunitas yang lahir, mekar, menjadi tua dan akhirnya hancur. Jadi Negara mempunyai umur yang sama dengan makhluk-makhluk yang lain. Ibnu Khaldūn berpendapat bahwa umur suatu negara adalah tiga generasi, sekitar 120 tahun, dimana satu generasi dihitung umur yang biasa bagi seseorang, yaitu 40 tahun. Tiga generasi tersebut adalah: (al-Khudhairi,1995:168). Pertama, Generasi Pertama; hidup dalam keadaan primitif yang keras, jauh dari kemewahan dan kehidupan kota. Masih tinggal di pedesaan dan padang pasir. Kedua, Generasi Kedua; berhasil meraih kekuasaan dan mendirikan negara, sehingga inipun beralih dari kehidupan primitif yang keras ke kehidupan 
kota yang penuh dengan kemewahan. Ketiga, Generasi Ketiga; negara mengalami kehancuran, sebab generasi ini tenggelam dalam kemewahan, penakut dan kehilangan makna kehormatan, keperwiraan dan keberanian dalam menghadapi pemberontak.

Pendirian negara mempunyai tahapan, ini merupakan tahapan untuk mencapai tujuan, menaklukkan segala halangan dan rintangan, serta menguasai kekuasaan. Negara sendiri tidak akan tegak kecuali dengan 'aṣhabiah. Sebab'așhabiah menurut Ibnu Khaldūn, membuat orang berupaya menyatukan sebuah tujuan yang sama, mempertahankan diri dan menolak atau mengalahkan musuh. Ada beberapa tahap bagi pendirian negara diantaranya mencakup; 1) Pemusatan kekuasaan, 2) menikmati kekuasaan, 3) ketundukan dan kemalasan dan ke 4) berfoya-foya yang kesemuanya dijelaskan sebagai berikut:

Pertama, tahap Pemusatan Kekuasaan. Menurut Ibnu Khaldūn, pemusatan kekuasaan merupakan kecenderungan yang alamiyah pada manusia. Pada waktu itu pemegang kekuasaan melihat bahwa kekuasaannya telah mapan, sehingga ia berusaha menghancurkan'ashabiah, memonopoli kekuasaan dan menjatuhkan anggota-anggota 'ashabiah dari roda pemerintahannya.

Kedua, tahap Menikmati Kekuasaan. Tahap untuk menikmati buah kekuasaan yang seiring dengan watak manusia. Seperti mengumpulkan kekayaan, mengabadikan peninggalan- peninggalan danmeraihkemegahan. Negara padatahap ini sedang berada pada puncak perkembangannya.

Ketiga, tahap Ketundukan dan Kemalasan. Pada tahap ini negara dalam keadaan statis, tidak ada perubahan apapun yang terjadi, dan negara seakan-akan sedang menantikan permulaan akhir kisahnya.

Keempat, tahap Foya-Foya dan Penghamburan Kekayaan. Negara pada tahap ini telah memasuk masa ketuaan dan dirinya telah diliputi penyakit kronis yang hampir tidak dapat ia hindari dan terus menuju keruntuhan.

Ibnu Khaldūn adalah seorang politisi yang sangat memahami dunia politik Islam, khususnya pada abad keempat belas. Dengan melihat terjadinya keruntuhan dan kelemahan yang menimpa 
dunia Islam pada umumnya ketika itu dan mengamati kemunduran kebudayaan Arab-Islam di Andalusia di bawah tekanan pasukan Spanyol, tidaklah mengherankan jika ia berpendapat bahwa segala sesuatu akan hancur.

\section{Sejarah Politik Umat Islam}

Menurut Ibnu Khaldūn, kekuasaan harus ada dalam masyarakat, untuk menjaga eksistensinya dan mengatur sistem interaksi muamalah antar mereka. Dalam konsepnya, kekuasaan harus didasari oleh 'ashabiyah (solidaritas), di mana sekelompok masyarakat yang mempunyai kesepakatan untuk mendirikan kekuasaan mempunyai komitmen yang sama. 'Ashabiyah ini bukan hanya karena pertalian darah, tetapi bisa dengan perjanjian, kesamaan nasib dan latar belakang. Hanya saja, memang harus diakui bahwa garis nasab (keturunan) sangat menentukan dalam regenerasi kekuasaan. Terjadinya kudeta dari sistem khilafah ke sistem kerajaan setelah Ali (Khulafaurrasyidin), membuat Ibnu Khaldūn semakin yakin tentang signifikansi konsep'ashabiyah-nya ini dalam tatanan politik saat itu (Al-Jâbiry, 1995:256).

Berdasarkan pemikiran ini, suatu negara yang dibangun dengan prinsip'așhäbiyah keturunan hanya akan bertahan selama empat generasi (Khaldūn, 1983: 136). Karena sampai ke generasi keempat, 'aṣhābiyah akan pudar dan runtuhlah negaranya. untuk tahap selanjutnya, kekuasaan akan beralih kekelompok yang mempunyai 'așhāabiyah yang lain. Tesis ini berangkat dari jatuh bangunnya negara pada masa lalu yang menganut sistem kerajaan. Sebagaimana yang diungkapkannya: "Ketahuilah bahwa kerajaan merupakan tujuan dari tabiat 'ashabiyah yang proses regenerasinya bukan dengan pemilihan, melainkan dengan garis keturunan secara berurutan"(Khaldūn, 1983: 202). Hal ini akan berbeda apabila sistem yang dianut adalah republik, di mana kekuasaan tidak terletak pada golongan tertentu, melainkan terletak pada rakyat. Rakyat yang memberikan mandat kepada pemerintah.

\section{Keunggulan Ibnu Khaldūn}

Ibnu Khaldūn merupakan seorang filosuf yang pertama kali mengungkap tabir hakikat filsafat sejarah. Di samping itu, ia juga menjabarkan posisi filsafat Arab dan pemikirannya yang mempunyai 
keunggulan dibandingkan pemikiran Yunani. Pendapat ini diperkuat dengan keberadaan filsafat al-Farabi, Ibnu Sina, Ibnu Rusyd dan lainnya. Ibnu Khaldūn telah mengupas hakikat epistemologi yang merupakan inti dari filsafat umum. Ia telah membahas permasalahan filsafat dan juga sejarah, sehingga pembahasan setelahnya hanya merupakan modifikasi yang tidak ada objeknya (Al-Āmily, 1988:331).

Prof. Smith, dari Amerika mengatakan bahwa Ibnu Khaldūn ialah seorang sejarawan, sosiolog dan filosuf seperti August Comte, Bekel, Spencer. Adapun menurut pemikir dari Jerman, Vont Visindong, sejarawan besar peradaban Islam hanya ada satu diTimur, tidak seorang pun yang meneruskan produktivitas berpikirnya. Orientalis Perancis merasa kagum dengan Ibnu Khaldūn, setelah karya Muqaddimah diterjemahkan oleh De Salan, sejarawan Maroko yang terkenal dan sekaligus filosuf sejarah. Gautier mengatakan bahwa Ibnu Khaldūn dan Saint Augustin merupakan pemikir besar yang dilahirkan olehAfrika utara (Gautier,1942: 80). Kemudian George Marcy mengatakan bahwa Muqaddimah Ibnu Khaldūn adalah salah satu dari sepuluh karya prestasi akal manusia (Lackus, 1982: 4). F.Lackus bersama George Lukacs mengatakan bahwa Ibnu Khaldūn adalahtokoh materialisme sejarah. Bahkan Lackus menamainya sebagai miracles dan pemuka besar cendekiawan Arab. Pada sisi lain ia membahas Ibnu Khaldūn lebih integratif, dalam sebuah pasal di buku tersebut, Mâdiyah Tärikhiyah wa Qawā̄in Jadaliyah yang mengungkap teori "Surplus Nilai" sebelum Karl Marx dan kaidah "Dialektika" sebelum Hegel. Di samping teori lain seperti filsafat evolusi sejarah dan kreasi barunya, ilmu sosiologi serta ilmu budaya.

Kebesaran pemikiran Ibnu Khaldūn telah banyak mempengaruhi filosuf Eropa dan pemikir pada masa pencerahan. Seorang pemikir berkebangsaan Aljazair, Prof. Nüruddin Haqīìi menulis sebuah buku yang menjelaskan pengaruh Ibnu Khaldūn terhadap pemikiran San Shimon, khususnya yang berhubungan dengan teori "autoritas peradaban." Sedangkan August Comte telah membicarakan permasalahan, sebagaimana yang dilakukan oleh Ibnu Khaldūn dalam pembahasan khusus yang bertemakan paradigma konvensional otoritas politik. Begitu juga, bahwa Ibnu Khaldūn, telah 
mampu membuka sinyal teori "Evolusi Biologi" sebelum dilontarkan oleh Herbert Spencer, teori "Pemindahan Solidaritas Mekanis" ke "Solidaritas unsur" sebelum didengungkan oleh Durkheim dan teori "Hegemoni Kekuasaan" sebelum disampaikan oleh Max Weber (Ismấil, 1988: 30-31) dan mungkin masih banyak komentar lain yang tidak mungkin penulis kemukakan semua di sini.

\section{Simpulan}

Konsep dan teori yang tertuang dalam magnum opusnya, Muqaddimah, telah memberikan inspirasi para intelektual Barat maupun Islam dalam membangun peradaban. Sejarawan Inggris, A.J. Toynbee menyebut Muqaddimah sebagai karya monumental yang sangat berharga. Bahkan Misbâh al-Āmily menjadikan pemikiran Ibnu Khaldu $>$ n sebagai variabel dalam melakukan studi komparatif antara pemikiran Arab dengan pemikiran Yunani (Al-Āmily, 1988: 5-8). Di samping itu, banyak sosiolog, filosuf, sejarawan dan ahli politik yang memuji kehebatan dan keluasan wawasannya.

Pemikiran Ibnu Khaldūn yang telah mengkristal dalam Muqaddimah, banyak mempengaruhi format peradaban masyarakat. Kebesarannya selama berabad-abad ternyata banyak mengundang komentar dari berbagai kalangan. Tidak sedikit yang memuji dan mengagumi karyanya, baik dari orientalis maupun pemikir Islam sendiri. Dalam hal ini, Mahmūd Isma'il juga mengakui kepiawaian Ibnu Khaldūn dalam menggulirkan ide-ide barunya berupa teori sejarah dan peradaban umat Islam, ia juga termasuk orang yang memberikan kontribusi dalam mempropagandakan teori ini di dunia Arab kontemporer. Bahkan ia pernah mengatakan bahwasanya Ibnu Khaldūn telah mendahului Montesque dalam teorinya tentang pengaruh milieu terhadap moral; Hegel dalam teori dialektikanya; Karl Marx dalam teorinya tentang urgenitas, social clash dan surplus nilai. 


\section{DAFTAR PUSTAKA}

Al-Āmily, Misbah. 1995. Ibnu Khald̄̄n; Wa Tawāfuq al-Fikr al-Araby 'Alā al-Fikr al-Yūnāny bi Iktisyāfihi Haqāiqil Falsafah, ad-Dār alJum̄huriyyah li an-Nasyr wa at-Tauzī' wa al-I'lân, cet I.

Al-Jâbiry, Muhammad 'Ābid. 1995. Naqd al-Aql al-Araby III; al-Aql as-Siyā̄asi al-Araby, Muhaddadātuhuwa Tajliyatuhu. Beirut: MarkazDirâsâtal- Wihdah al-Arabiyyah, cet III.

Al-Khudhairi, Zainab. 1995. Filsafat Sejarah Ibnu Khaldūn. Bandung: Pustaka.

Al-Qardawi, Yusuf. 1995. Min Fiqh ad-Daulah fi al-Islām. Cairo: Dâr AsSyuruq.

Al-Yâzijy, Kamâl dan Antaun Ghuthâs Karam. 1990. A'lāmal-Falsafah al'Arabiyah; Dirâsât Mufashalah wa Nuṣūṣ Mubawwabah Masyrūḥ ah, Maktabah Libnan, cet: IV.

Awwa, Muhammad Salim. 1983. Fi an-Nidzâm as-Siyâsi li ad-Daulah alIslâmiyah, Cairo: Maktabah al-Mishri.

Hidayat, Komaruddin. 1996. Arkaun dan Tradisi Hermeneutika, bunga rampai yang dimuat dalam buku: Tradisi, Kemodernan dan Metamodernisme, LKiS.

Ibnu Khaldūn, Abdurrahmân. 1983. Muqaddimah. Beirut: Dâr alQalam.

Isma'il, Mahmūd. 1998. Sosiolojia al-Fikr al-Islâmy; Muhawalah Tandzir, Cairo: Dar ats-Tsaqâfah.

Lackus, F. 1982. al-'Alâmah Ibn Khaldūun, terj. Bahasa Arab, Beirut - 1988. Fikrah at-Târikh; Bainal Islâm wal Marksiyah, Kairo. Isma'il, Saifuddin'AbdulFattah, 1998. Fi an-NadzriyyahAsSiyāsiyah Min Mandzū Islāmi, Cairo: IIT, cet. I.

Syaltūt, Mahmūd. 1959. Min Taujihât Al-Islām, Idârah Azharli Tsaqâfah Al-Islâmiyyah. 
halaman ini bukan sengaja dikosongkan 